\title{
Grafting guava on cattley guava resistant to Meloidogyne enterolobii
}

\author{
Enxertia da goiabeira sobre araçazeiros resistentes a Meloidogyne enterolobii
}

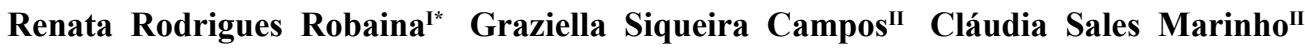 Ricardo Moreira Souza ${ }^{I}$ Cíntia Aparecida Bremenkamp ${ }^{I I}$}

\section{ABSTRACT}

The use of resistant rootstocks could be a promising method to control nematode Meloidogyne enterolobii in commercial plantations of guava. The present study aimed to evaluate the success of grafting guava as a scion on accessions of cattley guava as rootstocks resistant to $\boldsymbol{M}$. enterolobii. The treatments consisted of the rootstocks cattley guava plants (three accessions of Psidium cattleyanum) and common guava (control). In the apical wedge grafting method, scion of 'Paluma' cultivated variety was used. The experiment was arranged in a randomized block design with four treatments and five replicates, and eight plants per plot. The saplings produced as described before were planted in the field where the initial growth of the different combinations were evaluated. Graft success was observed for the control (common guava) and for accessions 115 and 117 of cattley guava plants, with success rates of 63, 32 and 29\%, respectively. In the field, the cattley guava used as rootstocks hampered Paluma canopy development and caused death of plants. Incompatibility of $\boldsymbol{P}$. cattleyanum as rootstocks for P. guajava Paluma was confirmed one year after cultivation in field.

Key words: Psidium guajava, Guava decline, guava root-knot nematode.

\section{RESUMO}

O uso de porta-enxertos resistentes poderá ser um método promissor para o controle do nematoide Meloidogyne enterolobii em plantios comerciais de goiaba, em caso de compatibilidade de enxertia. $O$ presente trabalho teve como objetivo avaliar o pegamento via enxertia por garfagem de topo em fenda cheia, entre a goiabeira e acessos de araçazeiros resistentes a M. enterolobii. Os tratamentos foram constituídos pelos porta-enxertos utilizados, araçazeiros (três acessos de Psidium cattleyanum) e a goiabeira. $O$ delineamento estatístico adotado foi em blocos casualizados (DBC), com quatro tratamentos, cinco repetições, e oito plantas por parcela. Após a enxertia, foi avaliada a percentagem de pegamento dos enxertos. As mudas produzidas foram plantadas no campo e avaliadas quanto ao crescimento inicial das diferentes combinações. Constatou-se pegamento de enxertia entre a goiabeira 'Paluma' e os porta-enxertos de goiabeira e araçazeiros dos acessos 115 e 117, ocorrendo uma taxa de pegamento de 63, 32 e 29\%, respectivamente. No campo, os araçazeiros utilizados como porta-enxertos induziram menor desenvolvimento de copa e resultaram em morte de plantas. A incompatibilidade entre a goiabeira 'Paluma' e o porta-enxerto $\boldsymbol{P}$. cattleyanum foi confirmada um ano após plantio no campo.

Palavras-chave: Psidium guajava, declínio da goiabeira, nematoides das galhas.

\section{INTRODUCTION}

In Brazil, 15,956 hectares were planted with guava (Psidium guajava L.) in 2011, mainly in the states of Pernambuco and São Paulo (IBGE, 2012). The promising market demand for this fruit has not been fulfilled because of nationwide decimation of guava orchards caused by guava decline. This is a complex disease in which parasitism by Meloidogyne enterolobii (syn. M. mayaguensis) (Yang and Eisenback, 1983) predisposes the trees to extensive root rot caused by Fusarium solani (Mart.) Sacc. (GOMES et al., 2011; GOMES et al., 2013; ALMEIDA et al., 2013). According to PEREIRA et al. (2009), the direct economic impact of this disease has been estimated at over 112.7 million reais.

\footnotetext{
ILaboratório de Entomologia e Fitopatologia, Universidade Estadual do Norte Fluminense Darcy Ribeiro (UENF), Av. Alberto Lamego, 2000, 28013-602, Campos dos Goytacazes, RJ, Brasil. E-mail: robainarr@yahoo.com.br. "Corresponding author.

"Laboratório de Fitotecnia, UENF, Campos dos Goytacazes, RJ, Brasil.
} 
Considering $M$. enterolobii as the factor that may trigger guava decline, this pest has been the focus of several attempts for the management of this complex disease. CARNEIRO et al. (2007) and MIRANDA et al. (2012) identified accessions of Psidium cattleyanum cv. 'Sabine' resistant to M. enterolobii and discussed about the possible use of these accessions as rootstocks for $\boldsymbol{P}$. guajava cv. 'Paluma' was speculated.

The use of resistant rootstocks is a promising method to control M. enterolobii if guava-compatible genotypes can be found. Such compatibility must be assessed through the evaluation of graft success and, subsequently, the growth and development of these plants in the field. Therefore, the present research aimed to verify grafting compatibility between guava and selections of $\boldsymbol{P}$. cattleyanum cv. 'Sabine' at the stage of nursery production and post-planting in the field.

\section{MATERIAL AND METHODS}

Two experiments were conducted, being the first in seedling production stage and another after planting seedlings in the field. In the first experiment, seedlings of three accessions of cattley guava (115, 116 and 117) were selected to be evaluated as rootstocks considering as resistant to $M$. enterolobii by MIRANDA et al. (2012). The common guava cv. 'Paluma' was used as rootstock too (control). The experiment was arranged in a randomized block design with four treatments, five replications and ten plants per plot.

Seedlings of these rootstocks were transplanted into conical pots with capacity of $3.8 \mathrm{~L}$. These pots were filled with Plantmax Hortaliças ${ }^{\circledR}$ substrate mixed and homogenized with Osmocote ${ }^{\circledR}$ slow release e NPK (17-07-12) and micronutrients formulation, with an average time of release scheduled for nine months, at an average temperature of $24^{\circ} \mathrm{C}$.

Thirty days after transplanting, the plants were assessed for stem diameter at collar and at $10 \mathrm{~cm}$ from the collar, plant height and number of leaves. The height was measured from the collar to the apical bud, using a ruler with an accuracy of $1 \mathrm{~mm}$, while the stem diameter was measured using a digital caliper.

Scions of $\boldsymbol{P}$. guajava cv. 'Paluma' with length and diameter ranging from 10.0 to $15.0 \mathrm{~cm}$ and 0.4 to $1.2 \mathrm{~cm}$, respectively, were used. The scions were removed from the canopy of guava trees cultivated in São João da Barra-RJ, Brazil, in the spring season. Each scion had four leaf buds and an equivalent diameter rootstock. The grafting procedure was performed by making a beveled cut in the scion of approximately $3 \mathrm{~cm}$ in length, with a very sharp stainless steel penknife. Then, with the aid of pruning shears, the rootstock was cut at the height of $15 \mathrm{~cm}$ and the leaves were removed. Subsequently, a longitudinal cut was made in the rootstock with a depth similar to that of the scion bevel so as to allow the two parts to fit together. The tissues of guava scion and rootstocks were joined by a strip of Parafilm ${ }^{\circledR}$, approximately $6 \mathrm{~cm}$ long and $1 \mathrm{~cm}$ wide. After fitting together, the scions were protected by $20 \times 10 \mathrm{~cm}$ plastic bags. This procedure aimed to form a moist chamber to prevent dehydration of the scion.

After grafting, the percentage of scion survival was assessed in five different periods. The scions were considered alive when buds were observed being still able to sprout. Graft success was assessed 160 days after grafting. The most vigorous and well positioned bud sprout was selected and conducted as a single stem.

The saplings produced as described above were planted in the field, in an area infested naturally by M. enterolobii, in São João da Barra-RJ, Brazil, where the initial growth of $\boldsymbol{P}$. guajava 'Paluma' graft on the different rootstocks was evaluated. The saplings were planted at a $7 \times 5 \mathrm{~m}$ spacing, in January 2011, and monitored until April 2012. Subsequently, the saplings produced as described before were planted in the field where the initial growth of the different combinations was evaluated.

The experiment was arranged in a randomized block design with four treatments, five replications and two plants per plot. The following treatments were carried out: T1- P. guajava 'Paluma' grafted on common guava as rootstock; T2-P. guajava 'Paluma' produced by herbaceous cuttings; T3 and T4 - P. guajava 'Paluma' grafted on accessions of P. cattleyanum which had achieved grafting success (115 and 117).

The plants were grown under uniform sprayer irrigation for all blocks. Fertilizations were performed according to recommendations for guava cultivation. Assessments of stem diameter were carried out every 30 days using a digital caliper. The plants produced by grafting were evaluated for growth of stem diameter of the rootstock and canopy, $4 \mathrm{~cm}$ below and above at the graft union. The stem diameter was also evaluated at the graft union.

The seedlings produced by herbaceous cuttings were evaluated for growth in stem diameter at $15 \mathrm{~cm}$ above the height of the collar. Height, diameter and volume of the canopy were also assessed.

The height of the plants was measured from the collar to the apex of the last sprout. The 
tree canopy diameter was measured in parallel and perpendicularly to the planting row (the mean was calculated from these two measurements). The canopy volume was estimated by the formula proposed by ZEKRI (2000): $\mathrm{V}=(\pi / 6) \times \mathrm{H} \times \mathrm{DL} \times \mathrm{DR}$, where V is the volume $\left(\mathrm{m}^{3}\right), \mathrm{H}$ is the plant height $(\mathrm{m}), \mathrm{DL}$ is the diameter that is parallel to the planting row and DR is the diameter perpendicular to it. One year after planting, $2 \mathrm{~cm}^{2}$ window openings were made in the grafting area to verify necrotic lines or spots. The fresh matter of root and shoot was also evaluated.

The data were subjected to analysis of variance and the means of the significant characteristics were compared by Tukey test $(\mathrm{P}<0.05)$. The data evaluated at different times were analyzed in a split-plot design. Then the curves with the best fit $\left(\mathrm{R}^{2}\right)$ were selected.

\section{RESULTS AND DISCUSSION}

It was confirmed that accession 115 of cattle guava showed the lowest growth rate, when compared with other treatments (Figure 1). At 196 days after transplanting, guava differed from cattley guava plants, with a greater mean height. In the same period, no difference was observed among the three accessions of cattley guava plants. Common guava plants presented a lower number of leaves than the cattley guava plants.

Regarding the growth in diameter at $10 \mathrm{~cm}$ from the collar, guava and accession 117 achieved the highest values at 196 days after transplanting, differing from accessions 116 and 115 (Figure 2). The diameters of guava and accession 117 were close to $10 \mathrm{~mm}$, while accessions 115 and 116 were between 7.5 and $7.9 \mathrm{~mm}$,

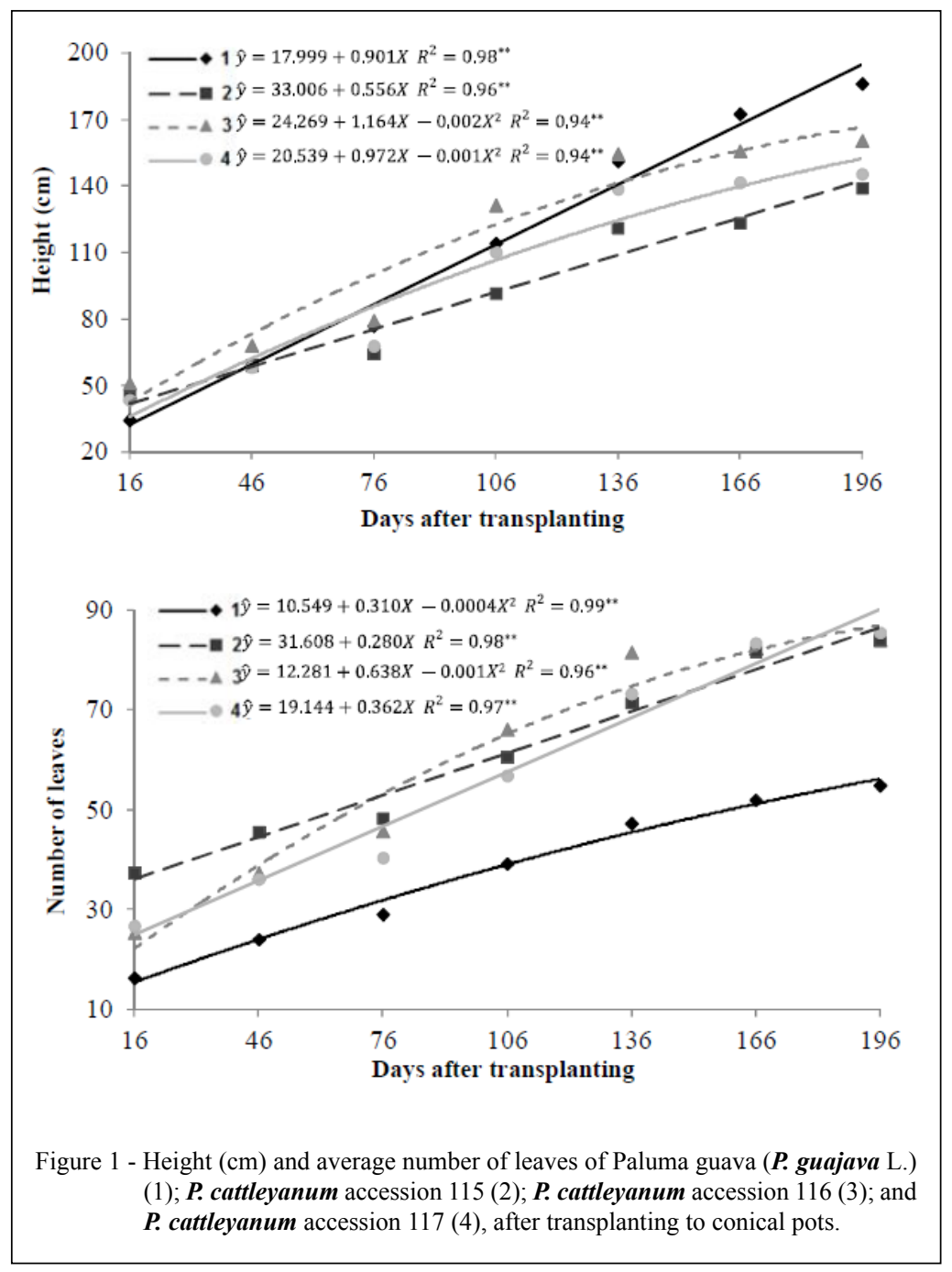

Ciência Rural, v.45, n.9, set, 2015. 


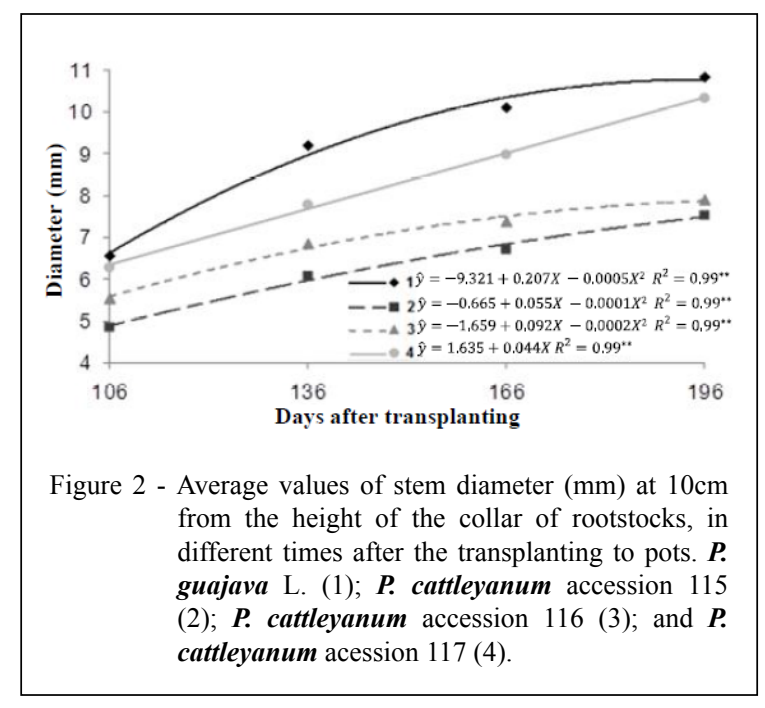

respectively. Forty days after grafting, the death of some scions started to be observed and the percentage of scion survival over time started to be evaluated (Figure 3). One hundred thirty days after grafting it was verified that survival rate stabilized, except for accession 116, whose survival rate was delayed until no scion survival was observed at 160 days after grafting. In accession 116 of cattley guava plants, scions initially sprouted and emitted leaves. Tissue welding of the rootstock and canopy in some plants was also observed. Over time, these shoots wilted and the scions died, which indicated incompatibility between this accession and P. guajava cv. 'Paluma'.

ROBAINA et al. (2012) assessed the fixation of inarching and did not observe survival of P. guajava 'Paluma' inarching with accession 116, either. The inarching using accession 116 of cattle guava presented tissue welding with guava, but the lack of functionality of the vascular tissues was observed.

Grafting success was observed between P. guajava cv. 'Paluma' and the rootstocks of guava reaching $63,3 \%$ while grafting success between Paluma and cattley guava plants from accessions 115 and 117, reaching 32 and $29 \%$, respectively. ROBAINA et al. (2012) observed low rates of inarching success between of $\boldsymbol{P}$ guajava 'Paluma' and accessions 115 and 117. The authors suggest incompatibility between the tissues of guava and of these accessions.

FRANZON et al. (2008) presented success percentage up to $42.5 \%$ for apical wed grafting for Eugenia uniflora in the winter. These authors also concluded that another grafting performed in spring in the same year presented the highest percentage of grafting success $(77.5 \%)$, which was higher than the grafting performed in winter. For these authors, this higher percentage could be related to the end of cold weather. In this period, increased intensity of plant metabolism could be observed, besides accelerated formation of vascular tissues and, ultimately, faster union of the parts.

In this research, grafting was performed in spring and the scions of guava should have the reserves needed to obtain higher rates of fixation. A rate of $65 \%$ for control (P. guajava/P. guajava) was observed, which is considered a good rate for this propagation method in this season.

In treatments graft fixation, the time for the production of the nursery was 16.4, 18.9 and 19.4 months after sowing, for the guava grafted on guava and for accessions 117 and 115 on cattley guava plants, respectively.

At 150 days after planting in the field (DAP), plants in all treatments presented a similar height, which reveals their initial uniformity (Table 1). However, at 210 DAP, differences were observed between treatments. At 300 DAP the greatest vigor in height was observed for guava grafted on guava, followed by guava from the herbaceous cutting. The lowest vigor in height was observed for the guava grafted on accessions 117 and subsequently for 115 cattley guava rootstocks.

It was observed that using cattley guava plants as rootstocks led to smaller canopy volume, contrasted with the treatments used as controls, and this corroborates the initial incompatibility observed (Figure 4). The values of the diameters of the trunk for the combination of $P$. guajava cv. 'Paluma'/ guava were superior to the other treatments in all measurements (Table 1). Besides the difference in

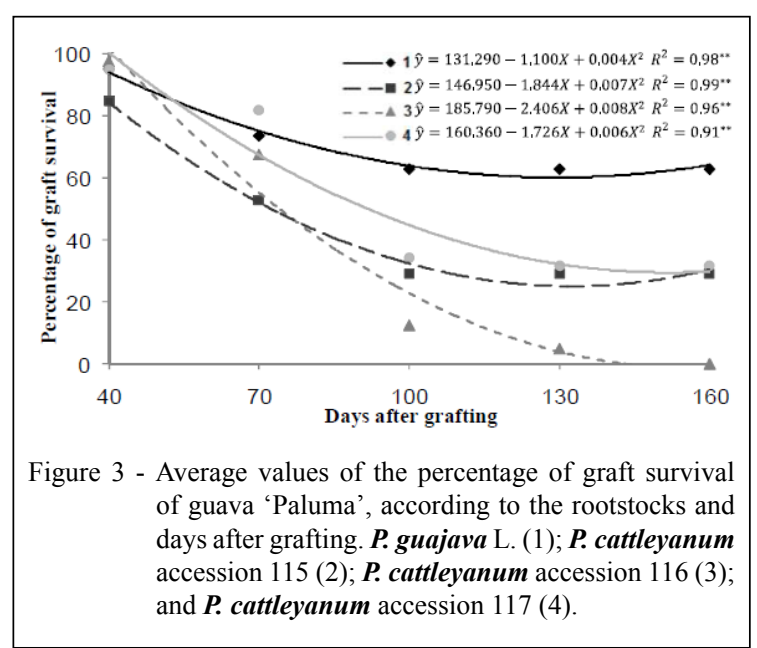


Table 1 - Average of height and diameter of 'Paluma' guava grafted on different rootstocks in diferent times before and after transplanting to the field - São João da Barra-RJ, Brasil.

\begin{tabular}{|c|c|c|c|c|c|c|}
\hline \multirow[b]{2}{*}{ Treatments } & \multicolumn{3}{|c|}{ 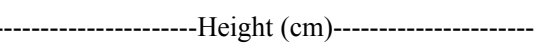 } & \multicolumn{3}{|c|}{-----------------Diameter (mm) (300 days)---------------- } \\
\hline & 150 Days & 210 days & 300 days & $\begin{array}{c}\text { Above the } \\
\text { grafting point }\end{array}$ & Grafting point & $\begin{array}{c}\text { Below the grafting } \\
\text { point }\end{array}$ \\
\hline 'Paluma'/P. guajava & $94.6 \mathrm{a}$ & $131.4 \mathrm{a}$ & $161.8 \mathrm{a}$ & $40.73 \mathrm{a}$ & $43.08 \mathrm{a}$ & $39.41 \mathrm{a}$ \\
\hline Cutting 'Paluma' & $80,4 \mathrm{a}$ & $111,3 \mathrm{a}$ & $141,6 \mathrm{a}$ & - & - & - \\
\hline 'Paluma'/acession 115 & $76.3 \mathrm{a}$ & $89.0 \mathrm{~b}$ & $117.7 \mathrm{~b}$ & $16.77 \mathrm{~b}$ & $24.40 \mathrm{~b}$ & $14.14 \mathrm{~b}$ \\
\hline 'Paluma'/acession 117 & $81.4 \mathrm{a}$ & $86.8 \mathrm{~b}$ & $95.9 \mathrm{c}$ & $13.51 \mathrm{~b}$ & $23.73 \mathrm{~b}$ & $12.98 \mathrm{c}$ \\
\hline
\end{tabular}

Averages followed by the same letter in the column do not differ by Tukey test $(\mathrm{P}<0.05)$.

diameter, the combinations $\boldsymbol{P}$. guavaja cv. 'Paluma'/P. cattleyanum showed greater diameter at the graft line as symptoms of severe hypertrophy (Figure 5). According to MORAES et al. (2011), this difference in graft line defines the type of incompatibility. This symptom can be attributed to obstacles to the translocation of the assimilates produced in the aerial part, due to poor connection of the conducting vessels. Hypertrophy or reduced growth in the grafting point retards the transport of nutrients, thus hindering plant development.
In the field, symptoms of nutrient deficiencies were observed in plants grafted on cattley guava plants, including falling leaves and cracks in the bark of the rootstock, while the controls did not present such symptoms. Incompatibility is usually recognized by low rate of graft survival, yellowing of leaves, defoliation and growth failure, curling leaves and plant death, marked differences between the growth rates of rootstock and cultivar, overgrowth of the grafting point, or the area close to it, and rupture of the grafting point (GONZÁLEZ, 1999). In this context, incompatibility

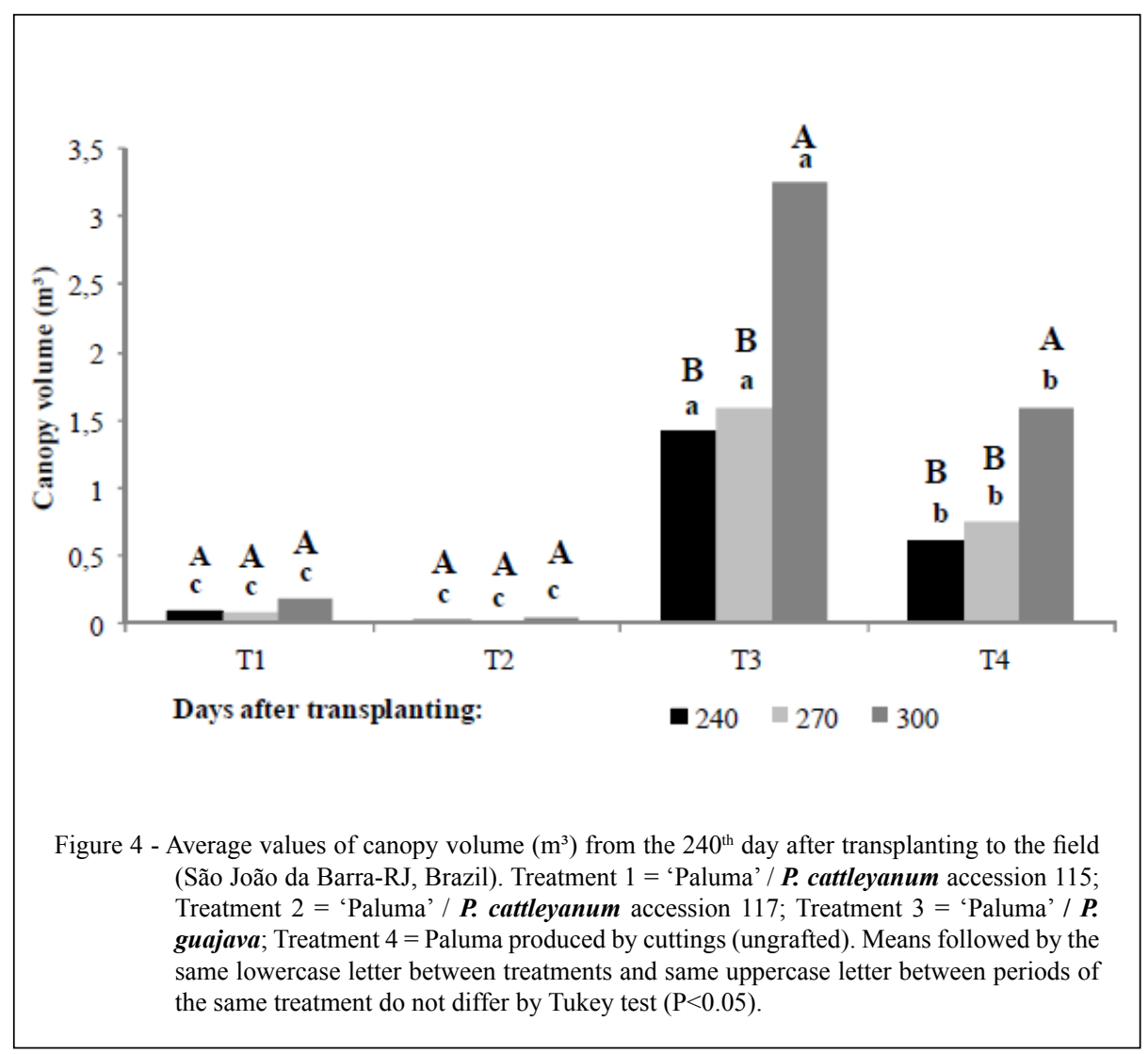

Ciência Rural, v.45, n.9, set, 2015. 


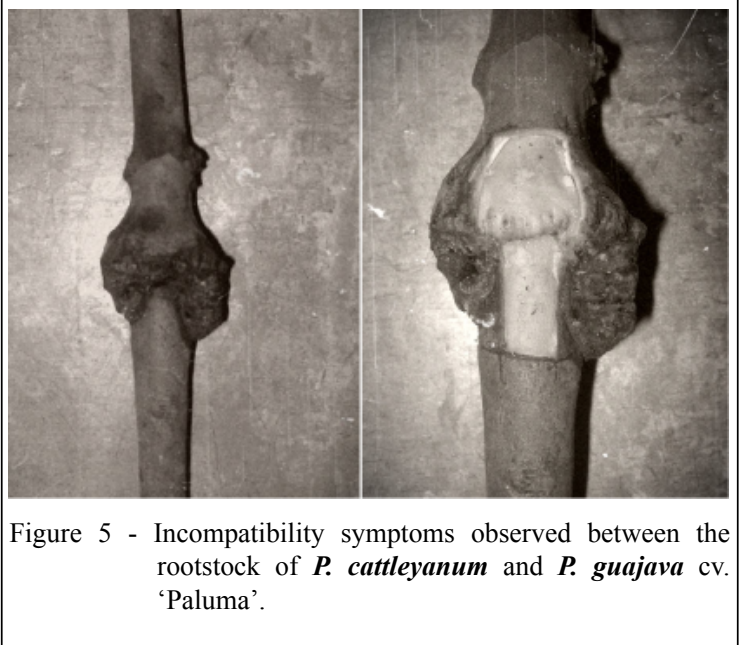

between the rootstock of accessions $\boldsymbol{P}$. cattleyanum and $\boldsymbol{P}$ guajva cv. 'Paluma' can be noticed (Figure 5).

\section{CONCLUSION}

The lower rate of graft success verified between $\boldsymbol{P}$. guajava cv. 'Paluma' and $\boldsymbol{P}$. cattleyanum cv. 'Sabine' plants, low sapling vigor in the field and symptoms of incompatibility demonstrate unviability for the use of cattley guava accessions as rootstock for 'Paluma' guava.

\section{ACKNOWLEDGEMENTS}

We thank Coordenação de Aperfeiçoamento de Pessoal de Nível Superior (CAPES) for the scholarship for the first author.

\section{REFERENCES}

ALMEIDA, A.M. et al. Field assessment of meat and bone meal for management of orchards affected by guava decline. Neamatropica, v.43, p.247-253, 2013. Available from: <http:// journals.fcla.edu/nematropica/article/view/82715/79658>. Accessed: Jan 21, 2014.

CARNEIRO, R.M.D.G. et al. Resistance to Meloidogyne mayaguensis in Psidium spp. accessions and their grafting compatibility with $\boldsymbol{P}$. guajava cv. 'Paluma'. Fitopatologia Brasileira, v.32, p.281-284, 2007. Available from: $<$ http://www.scielo.br/scielo.php?script=sci_arttext\&pid $=\mathrm{S} 0100-41582007000400001>$. Accessed: Jan. 14, 2013. doi: 10.1590/S0100-41582007000400001.

FRANZON, R.C. et al. Propagação de pitangueira através da enxertia de garfagem. Revista Brasileira de Fruticultura, v.30, p.488-491, 2008. Available from: <http://www.scielo.br/scielo. php?pid $=$ S0100-29452008000200038\&script $=$ sci_arttext $>$. Accessed: Jan. 14, 2013. doi: 10.1590/S0100-29452008000200038.

GOMES, V.M. et al. Guava decline: A complex disease involving Meloidoyne mayaguensis and Fusarium solani. Journal of Phytopathology, v.159, p.45-50, 2011. Available from: <http:// onlinelibrary.wiley.com/doi/10.1111/j.1439-0434.2010.01711.x/ abstract>. Accessed: Jan. 14, 2013. doi: 10.1111/j.14390434.2010.01711.x

GOMES, V.M. et al. Guava decline: effect of root exudates from Meloidogyne enterolobii-parasitized plants on Fusarium solani in vitro and on growth and development of guava seedlings under controlled conditions. European Journal of Plant Pathology, v.137, p.393-401, 2013. Available from: <http://link.springer.com/ article/10.1007\%2Fs10658-013-0251-2>. Accessed: Jan. 22, 2014. doi: 10.1007/s10658-013-0251-2.

GONZÁLEZ, J. El injerto en hortalizas. In: VILARNAU, A. GONZÁlEZ, J. PLANTELES: semilleros, viveros. Reus: Ediciones de Horticultura, 1999. p.121-128.

INSTITUTO BRASILEIRO DE GEOGRAFIA E ESTATÍSTICA (IBGE). Available from: <http://www.ibge.gov.br>. Accessed Jan. 02, 2013.

MIRANDA, G.B. et al. Avaliação de acessos de Psidium spp. quanto à resistência a Meloidogyne enterolobii. Bragantia, v.71, p.52-58, 2012. Available from: <http://www.scielo.br/scielo. php?pid $=$ S0006-87052012000100009\& script $=$ sci arttext $>$. Accessed: Jan. 21, 2013. doi: 10.1590/S0006-87052012005000001.

MORAES, L.A.C. et al. Incompatibility of Cleopatra mandarin rootstock for grafting citrus in Central Amazon, State of Amazonas, Brazil. Revista de Ciências Agrárias, v.54, p.299-306, 2011. Available from: <http://www.periodicos.ufra.edu.br/index.php/ ajaes>. Accessed: Jan. 17, 2013. doi: 10.4322/rca.2012.026.

PEREIRA, F.O.M. et al. Estimativa do impacto econômico e social direto de Meloidogyne mayaguensis na cultura da goiaba no Brasil. Nematologia Brasileira, v.33, p.176-181, 2009.

ROBAINA, R.R. et al. Subenxertia da goiabeira 'Paluma' com araçazeiros resistentes a Meloidogyne enterolobii (syn. M. mayaguensis). Revista Brasileira de Fruticultura, v.34, p.951-955, 2012. Available from: <http://www.scielo. br/scielo.php?pid=S0100-29452012000300041\&script $=$ sci arttext $>$. Accessed: Jan. 23, 2013. doi: 10.1590/S010029452012000300041 .

YANG, B.Y.; EISENBACK, J.D. Meloidogyne enterolobii n.sp. (Meloidogynidae), a root-knot nematode parasitizing Pacara Earpod Tree in China. Journal of Nematology, v.15, p.381-391, 1983. Available from: <http://www.ncbi.nlm.nih.gov/pmc/articles/ PMC2618283/pdf/381.pdf $>$. Accessed: Jan. 19, 2014.

ZEKRI, M. Evaluation of orange trees budded on several rootstocks and planted at high density on flatwoods soil. Proceedings of Florida State Horticultural Society, v.113, p.119-123, 2000. Available from: $<$ http://fshs8813.wpengine.com/proceedings-o/2000vol-113/119-123\%20\%28ZEKRI\%29.pdf >. Accessed: Jan. 17, 2013. 